Saeculum Christianum

vol. XXIII (2016)

pp. $14-22$

\title{
LUCA CAPANNOLO
}

\section{IN RE OBSCURA VERSANTES. THE COMPLEX HAGIOGRAPHY OF THE MARTYRS OF AMITERNUM AND NEW WAYS OF ITS INTERPRETATION}

Martyrs are among the most common and well-known profiles of early Christian sainthood: virtually all saints from the first centuries CE professed their faith through martyrdom. In most cases, their lives are well-documented through literary, historical, archaeological, and epigraphic records.

However, accurate and comprehensive records on some martyrs are not as widely available. One of the more prominent cases of such lack of information are the Martyrs of Amiternum, whose cult had gradually waned, despite its popularity in the first centuries. Although some ancient records on the Martyrs of Amiternum do exits, they have garnered no interest among modern scholars. Hence, the scant available information, the res obscura of their biographical history, has not yet been properly collected and organized. There is no new published material on the issue and it is still not known how the study of the Martyrs of Amiternum developed over the last few centuries. The few existing pieces of information come from spurious pages from different multidisciplinary works: the martyrs are mentioned in historiographic works, hagiographic texts on local saints, and even in old historical and artistic descriptions of the Diocese of L'Aquila (from where the cult originates). The few scholars who decided to study the biographical history of the Martyrs of Amiternum relied on borrowed material, which, despite ancient and common veneration, remains the only record of the their lives. The absence of information does not mean, however, that the subject is somehow less worthy of study, especially if we take into account the fact that the Martyrs are still widely revered in the Sabino and Amiternum communities. The collected data, though limited and disorganized, can be used to produce summary results of the long-abandoned investigation (status quaestionis) into the lives of the Martyrs of Amiternum. The data also allow for new ways of analyzing and organizing the available hagiographic material.

The hagiography of the Martyrs of Amiternum has recently become even more relevant with the opening of the newly renovated Christian burial site in the catacombs of the Church of Saint Michael the Archangel (Chiesa di San Michele Arcangelo) in San Vittorino in the L'Aquila comune.

\section{Records of the Martyrs' lives}

Little is known about the lives of the Martyrs of Amiternum. Their biography is, in a sense, an apophatic one because it contains many uncertainties: their names have not been 
transmitted from one generation to another, their place of birth is unknown, the information on how they converted to Christianity is not available, and any potential Acta are missing. Finally, it is not even known when they were martyred. Their biographical history has been reconstructed by modern scholars with the use of past records, mainly oral testimonies and accounts based on documents that had been destroyed or lost.

In his brief hagiographic tradition, Domenico di Sant'Eusanio, a historian and a Franciscan monk, provides the best reconstruction of the hagiographic profile of the Martyrs of Amiternum, devoting an entire chapter of his Aquila Sacra to their lives.

Among the ruins of Amiternum stands the ancient Church of Saint Michael the Archangel, which is commonly known as San Vittorino and which lends its name to a nearby village located four and a half miles from L'Aquila. Underneath the church, there is cave complex, in which the relics of two St. Victorians were venerated (and which will be described in more detail elsewhere). In these caves, which were excavated in a manner similar to Roman catacombs, the relics of eighty-three soldier saints were preserved. The martyrs are commemorated in the Roman Martyrology on the 24th of July with the following words: Amiterni in Vestinis passio Sanctorum Militum octogintatrium; while in San Vittorino the 24th of July is celebrated as a holiday ${ }^{1}$.

Domenico di Sant'Eusanio deals swiftly and comprehensively with the issues related to the lives of the Martyrs of Amiternum. According to his report, the only confirmed elements of the story (i.e., ones that are corroborated by other sources) include the number of the martyrs (eighty-three), their profession (soldiers), and their martyrdom (they were killed through torture). Another crucial information pertains to the bodies of the martyrs. After the execution, their bodies were buried on the Christian cemetery in Amiternum, near the tomb of Victorinus, the first bishop of the local diocese.

\section{Preliminary analysis}

Before the complex hagiography of the Martyrs of Amiternum can be properly addressed, a preliminary analysis must be conducted. In other words, the physiognomy of the cult must be cleared of any potential interrelated confounds. Amiternum, similarly to other Italian cities around Rome, was an early center of Christian culture. And thus, it was characterized by an indigenous model of sainthood and martyrdom, or to be more precise, a model of a bishop. There are two most prominent examples of that: Victorinus (Vittorino), a well-known martyr and the first bishop of the Diocese of Amiternum, who was tortured in the nearby Cotilia; and Ceteo (or Cetteo), a lesser-known bishop from a later period, who was killed for political reasons during the Lombard invasion of Italy.

Although the cults of these martyred bishops were separated by a considerable amount of time (as a matter of fact, only veneration of Victorinus was common, while there are no reliable sources recounting an established cult of Cetteo), they eclipsed the cult of the Martyrs of Amiternum, reducing its status to a secondary, sheer reverence. The eighty-three martyrs were always in the background, without their own confirmation.

\footnotetext{
Domenico di Sant'Eusanio, L'Aquila Santa, o sia Vite dei Santi, Beati ed altri servi insigni di Dio o nati o morti o presentemente riposanti col Corpo nella città dell'Aquila in Abruzzo, 1846, pp. 276-277.
} 
The situation is exacerbated by the close proximity of their burial sites. Both the Martyrs of Amiternum and Victorinus were buried in the same catacombs. The Martyrs thus occupy a place of worship that is dominated by another cult ${ }^{2}$. At a later period, a church was built over the bishop's tomb and a complex system of tunnels and underground chambers was built around it in the early centuries.

However, no precise information about the tomb where the Martyrs were buried is available.

\section{The contents of martyrologies}

The first martyrology that mentions the Martyrs of Amiternum is the Martyrologium Adonis. It contains the following brief mention for the 24th of July (IX Kalendas Augusti):

Et apud Amiterninam civitatem, Militum octoginta trium ${ }^{3}$.

The scant information, in accordance with the basic structure of martyrologies, suggests that the ancient biographic history of the Martyrs was largerly ignored.

The Martyrs of Amiternum are also mentioned in the Martyrologium Hieronymianum, which contains their laudations from the Codices E (Epternacensis), B (Bernensis) and W (Wissenburgensis).

E LXIII rom victorini militaris

B UIII KL. AGS. IN AMIT(ER)NINA ciuitate. milites octoginta tres. AB URBE ROMAna. Uia Salaria. Nati Uictorini

W VIII KL AG In amiternina ciui militis LXXXIII ab urbe romana uia salutaria nat sci uicturini ${ }^{4}$.

These rather jumbled and unclear pieces of information are not particularly helpful in shedding light on the hagiography of the Martyrs, as the martyrology mentions the martyrdom of bishop Victorinus on the same day, despite it being normally commemorated in September. The Codex E mentions only the number of militaris martyrs and, as an example of a martyr par excellence, it references Victorinus (victorini). The two other codices, despite containing additional information, do not solve this issue. The Codex B explicitly states the date of commemoration (UIII KL.AGS.), the exact place of martyrdom (IN AMIT(ER)NINA ciuitate,), and the number of the martyrs and their profession (milites octoginta tres). Nevertheless, the veracity of this information is to be doubted due to the commemoration of the martyrdom of bishop Victorinus (Nati Uictorini). Codex W contains a near-verbatim transcription of the information from the Codex B, adding only additional information on the martyrdom of Victorinus. Analysis of the three codices demonstrates that the principle of anonymity

\footnotetext{
2 "In the city of Amiternum, (...) under the parish church, there lies an ancient burial ground, similar to the one we have in Rome, carved out in rock with tombstones on the walls. It is commonly believed that this is where many Martyrs were buried, especially the aforementioned eighty-three", M.A Boldetti, Osservazioni sopra i cimiteri de santi martiri ed antichi christiani di Roma. Aggiuntavi la serie di tutti quelli, che fino al presente si sono scoperti, e di altri simili, che in varie parti del mundo si trovano: con alcune riglessioni pratiche sopra il culto delle sagre reliquie, Giovanni Maria Salvoni, Rome 1720, p. 603.

3 Martyrologium Adonis archiepiscopi viennensis ab Heriberto Rosweido societatis Juesu Theologo jam pridem ad Mss. exemplaria recensitum, ex Typographia Palladis, Romae, MDCCXLV, p. 351.

4 Cfr. Martyrologium Hieronymianum w Acta Sanctorum LXXXII Iulius, part II, Bruxelles 1971.
} 
of the martyrs is strictly observed in each codex. Only the number of the martyrs is stated, with no mention of how they were martyred. It should also be noted that mistakes made by copyists can be found in both the abbreviations and the transcripts. One such mistake is the change from Via Salaria to uia salutaria.

In the first editions of Martyrologium Romanum, the Martyrs are not commemorated and on the 24th of July only bishop Victorinus is mentioned by name. However, the opposite is true in the case of the modern edition of the same martyrology, i.e. the Martyrs of Amiternum are referenced, while there is no mention of Victorinus and his commemoration is rightly moved to September. All editions agree that Amiterni in Vestinis passio sanctorum Militum octoginta trium, but they contain no additional information. In the 1621 edition of the Martyrologium Romanum, only the number of martyred soldiers and the place of their martyrdom is provided.

In Amiternum in Abruzzo it is the martyrdom of eighty-three martyrs.

In the new reprints of the same martyrology that were amended and corrected in modern times (specifically in 1668 and later in 1770), the complex hagiography of the Martyrs is solved by reinstating their commemoration, without, however, any biographic information. Both version include the same piece of information:

In Amiternum in Abruzzo it is the martyrdom of eighty-three martyrs.

In the 1668 edition, a brief note containing a hypothetical date of their martyrdom (Circ. il 318.) had been added on the margin.

A more detailed analysis of the complex hagiography of the Martyrs of Amiternum was conducted by J. Bolland in Acta Sanctorum. Under the $24 \mathrm{~h}$ of July, he provided an overview of this issue:

Clarissima est hoc die \& nitidissima codicum Lucensium annuntiatio in laterculo Florentinii: in Amiternina civitate, milliario LXXXIII ab urbe Roma, via Salutaria (pro Salaria) natalis sancti Victorini. In Epternacensi lucis nihil, quin potius tenebrae, unde confusio suboriri potuis: misce enim sus deque omnia, ut ex relato superius textu abundo constat. Codex Corbesensis Lucensibus persimilis est: In Amiternina civitate, miliario octogesimo tertio ab urbe Roma, via Salaria, natalis Sancti Victorini martyris. Atque hic procul dubiogenuinus textus est ex aliis minoribus, apographis confirmatus, notanter ex codice contracto Reginae Sueciae, ut proinde affatim sudet Florentinius ad Haec cum Romano concilianda, si Martyres isti LXXXIII ex Hieronimianis accepti censeantur; quandoquidem ibi \& breviores Armeniae tribuantur; aut si cum Victorino conjungendi sunt. Dicamus potius, ab Adone nescio unde productos, sic eos descripsisse Usuardum, quo modo hoc die celebrantur a Romano, in quo S. Victorinus Amiterninus episcopus ex iisdem suis fontibus ponitur V Septembris: idem an alius ab eo qui hoc die in Hieronimianiis refertur, usque adeo exploratum non est: maluimus nos hodiernum Victorinum, quisquis is est, loco suo ex citatis codicibus servare, atque una adjungere classem alteram undecumque desumptam, quid quid dubium non nulliis sit, an non ex mera jam satis indicata confusione proficiscatur ${ }^{5}$.

\footnotetext{
5 Acta Sanctorum, iulii a Ioanne Bollando S.I. Collegi feliciter coepta, II, Editio novissima curante I. Carnandet, Parisiis - Romae, apud Victorem Palme, 1865, p. 50.
} 
J. Bolland is visibly confused by the biographical history of the Martyrs, as it was widely disseminated but never fully explained and understood. The issue of the Martyrs of Amiternum illustrates how complex the stratification of ancient records is and how fragile they turn out to be when confronted with Bollandist investigations. What remains is the strong presence of bishop Victorinus, to whom almost the entire biographical analysis of the martyrs was devoted.

\section{Other literature}

Despite the fragmentary nature of the historical records on the Martyrs of Amiternum, it should be noted that all martyrologies (or at least all the major ones) include at least a brief mention of the Martyrs. A different view of the issue is presented in other types of works. In fact, there are many texts that mention the Martyrs of Amiternum, or, to be more precise, attempt to collect and organize all the available information. These texts have a general scope and fall under one of the following types: memoirs, collected biographies of saints, prayer books, commentaries, guidebooks, and descriptions, which mentioned mysterious soldiers killed because of their faith.

There are many books that reference the issue, but few go beyond a superficial analysis.

The oldest one is the Compendio delle vite di tutti $i$ santi ${ }^{6}$ by L. Zacconi, printed in Venice in 1612. After the first publication, a series of heterogeneous texts were relseased: Risolutione per l'eternità a spiritual guidebook written by D. De Rosis, a Jesuit scholar published in Naples in 1665; Emerologio sagro di Roma cristiana e gentile 8 by abbot C. Bartolomeo Piazza from 1690; Osservazioni sopra i cimiteri de' $i$ santi martiri ed antichi cristiani di Roma ${ }^{9}$ an archeology text by M.A. Boldetti; Acta of martyrs such as Acta S. Victorini episcopi Amiterni, et Martyris ${ }^{10}$ by protonotary apostolic G. Marangoni also printed in Rome in 1740.

There are also local texts on the lives of martyrs, such as Relazione dello scoprimento del corpo e degli atti antichi del glorioso sacerdote e martire S. Eusanio ${ }^{11}$ by bishop and Oratorian Aquili G. Coppola and Aquila Sacra ${ }^{12}$ by the aforementioned Franciscan D. di Sant'Eusanio.

\section{Different perspectives}

There are still many doubts and uncertainties surrounding the Martyrs of Amiternum. Despite conducting a thorough analysis of not only hagiographic texts, but also archaeological, historical, and literary ones, the biography of the Martyrs is still far from complete. What

\footnotetext{
6 L. Zacconi, Compendio delle vite di tutti i santi descritte non solo dal Vigliega nel lodatissimo suo Flos Sanctorum, ma anco dal Voragine, Fiamma, Surio, Pietro di Natale, \& altri, Sebastiano Combi, Venice, 1612, p. XVI.

7 D. De Rosis, Risolutione per l'eternità, wydawnictwo Giacinto Passaro, Neapol 1665r., pp. 61-62.

8 C.B. Piazza, Emerologio sagro di Roma cristiana e gentile, Domenico Antonio Ercole, Rome1690r., p. 75.

9 M.A. Boldetti, Osservazioni sopra i cimiteri...ibid.

10 G. Marangoni, Acta S. Victorini episcopi Amiterni, et Martyris illustrata: Atque de ejusdem, ac LXXXIII. SS. Martyrum Amiternensium Coemiterio prope Aquilam in Vestinis Historica Dissertatio, wydawnictwo Giovanni Maria Salvoni, Rome 1740, pp. 32-33.

11 G. Coppola, Relazione dello scoprimento del corpo e degli atti antichi del glorioso sacerdote e martire S. Eusanio esposta alla pubblica luce, Antonio de' Rossi, Rome 1749, p. 22.

12 D. da Sant'Eusanio, L'Aquila Santa..., ibid.
} 
is now necessary is to summarize the issue and attempt to explain the collected material, illustrating it, and suggesting new ways of interpretation of some points in the hagiography of the Martyrs.

Most sources agree that the soldiers were martyred in Amiternum, a Sabine city located a few kilometers north-west of L'Aquila; however, not all hagiographies are as precise in determining the place of their martyrdom. In some copies of the Martyrologium Adonis, the martyrs are said to had been killed in Armenia, rather than Amiternum - a mistake that must have been caused by a misreading of the abbreviation for Amiternum. Similarly, it should be noted that some records provide only a very general location of the place of martyrdom, putting it within the Vestini territory (in Vestinis). This geographical misidentification is most likely caused by the close proximity of the Vestini territory to Amiternum, as the two areas share a common border.

The number of martyrs and their profession are similar in this regard. All records state that there were eighty-three martyrs (there are no records that contradict this information) and that all of the martyrs were soldiers (milites). The only text that provides a different version is the Martyrologium Hyeronimianum, in which, due to a copyist's mistake, the term milites was confused with miliario, i.e. distance in miles from Rome. Military sainthood is not a new element in the history Amiternum, which, despite a rather primitive model of a bishop saint, is the place of origin of military martyrs, such as Menas from Egypt, whose cult was introduced by a contingent of Nubians, banished because of their faith to a forest in Abruzzo.

The issue of anonymity is probably the most intriguing and complex aspect of the story of the Martyrs of Amiternum. All records keep the identity of the martyrs anonymous. In Acta Sanctorum, they are also mentioned as Anonymis. The anonymity of the Martyrs was a serious issue for later hagiographers, as it could potentially undermine the validity of their hagiographic studies or, even worse, cast doubt on the very existence of the Martyrs themselves. In modern times, considerable attempts to remedy this "name crisis" were made. The most significant one was made by C. Baronio, who noticed the following two names in his revision of Martyrologium Romanum:

Fuerunt hujus cohortis praecipui Florentius, \& Felix ut ex M. SS. Aquila transmissis accepimus $^{13}$.

The shortcoming of this attempt is rather obvious: only two names (Florenzo and Felice) were remembered, out of a company of eighty-three martyred soldiers. C. Baronio's conclusion is made even less reliable by a historical coincidence. The day after the soldiers of Amiternum were martyred, two other non-military martyrs from Siponto were killed in the nearby Forcona, which was under the control of the Vestini. The mistake made by C. Baronio goes unnoticed by F. Ferrari, who, by adopting the information of his predecessor, states that:

13 C. Baronio, Martyrologium Romanum cum Notationibus Caesaris Baronii, apud Typographia Dominici Base, Rome 1586, p. 327. These two names are also mentioned in a geographical text, which describes the Kingdom of Naples. The chapter devoted to Amatrice reads as follows: "S. Vittorino le diè onore con la pretios'aureola di Martire la persecutione di Nerva. Illustrolla parimente il Trionfo di ottantatrè Campioni di Christo, fra cui spiccano i Santi Fiorenzo, e Felice, venerati nell'Aquila e riferiti dal Baronio, e Ferrari.", w G.B. Pacichelli, Il Regno di Napoli in prospettiva in cui descrivono la sua metropoli città di Napoli e le cose più notabili e curiose così di natura come d'arte, Naples, Stamperia di Michele Luigi Mutio 1703, p. 59. 
De Ss. Martyribus Lxxxiii. Amiterni

Octogintatres Milites Sipontini, ex quorum numero fuere Florentius, \& Felix fratres, qui apud Furconiumvrbem Vestinorum, Amiterno proximam postridie passi sunt; quod Christiani essent, comprehensi, cum ad Idolorum cultum nullis tormentis reuocari potuissent, corona martyrij donati sunt 9. Kal. Aug. Ex Pass. SS. Florentij, \& Felicis, ac S. Iusta virg.

\section{Annotatio}

De ijs agitur in Ecclesia Aquilana, qua cum Furconio, \& Amiterno urbibus successerit, SS. martyrum reliquias asseruat, \& veneratur. 14

The confusion is completely resolved thanks to the intervention of A.L. Muratori, who emphasizes in Antiquitates that the issue was not a trivial one because of the lack of sources of reliable historical information. To avoid posing further hypotheses, he decided to separate the eighty-three Martyrs of Amiternum from the aforementioned Florenzio and Felice ${ }^{15}$.

The discussion of martyrdom of the soliders was still ongoing. Bishop Victorinus distinctly recalls the death of the martyrs in the sulfur springs in Cotilia, but in the case of the Martyrs of Amiternum most witnesses do not recall any details. There are, however, two records that might help us understand how the soldiers were martyred: the first and the oldest one is a fresco in the Church of Saint Peter in Sassa (San Pietro di Sassa) in L'Aquila; and the second one is a description of a mural painting in Acta Sancti Victorini by G. Marangoni. No information is available on the fresco because the Church of San Biagio (Chiesa di San Biagio, previously San Pietro di Sassa) suffered extensive damage during the 2009 earthquake and was condemned. It remains closed-off since then ${ }^{16}$. The records from Acta Sancti Victorini are more consistent and include precise references, as they are also based on the cult and some cult objects, which were preserved in the Amiternum catacombs till the last century. The Acta state that was an altar in a side niche by the main passageway of the catacombs. The niche also stored relics of martyrs, an instrument of torture, and, what is especially significant, a painting portraying the martyrdom. The author accurately quotes:

Pluribus autem tormentis cruciatos fuisse, apparet ex antiquissimis picturis, quae supersunt in Confessione [...] ubi cernuntur SS. Martyres manibus suspensis excarnificari ungulis; constansque traditio viget, ad Columnam etiam tortos fuisse, quae adhuc eorum Sanguine aspersa apparet in eadem confessione erecta. In gradibus praeterea, quibus pavimentum Ecclesiae elevatur habetur marmor, in quo duo cernuntur vestigia, pedis unum, alterum manus, quae miracolose impressa dicuntur, ex antiquissima traditione, in horum Sanctorum Martyrio: Quae vestigia cratibus ferreis obducta sunt ${ }^{17}$.

This representation is quite vivid and constitutes a reference to ancient tradition, preserved and transmitted also through the ex antiquissimis picturis iconography. The author concludes

\footnotetext{
${ }^{14}$ F. Ferrari, Catalogus Sanctorum Italiae: in menses duodecim distributus, apud Hieronimum Bordonium, Mediolani 1613, p. 456.

15 L.A. Muratori, Antiquitates italicae medii aevii, sive dissertationes de moribus, ritibus ..., ex Typographia Societatis Palatinae in Regia Curia, Milan, 1738, vol. IV, pp. 487 and pp.

${ }^{16}$ Cfr. L. Rivera, Raffaello e varie memorie, w Bollettino della Regia Deputazione abruzzese di Storia Patria, p. III, a. XIII, December 1921, p. 295.

17 G. Marangoni, Acta S. Victorini episcopi Amiterni..., ibid., p. 33.
} 
that the soldiers from Amiternum were martyred over three separate occasions which correspond to three different methods of torture: hanging and denailing; flagellation while bound to a post; and laceration with iron rakes (cratibus ferreis) that were used to finally kill the eighty-three soldiers by tearing their flesh to pieces.

With regard to the different hypotheses on the soldiers' martyrdom, it is also worth mentioning the one proposed by Domenico di Sant'Eusanio, who recognized directs signs of martyrdom in church reliefs:

The significance of martyrdom suffered by these Heroes of Christian Faith in the early third-century can be ascertained from an ancient Church tablet from the fourth or at least fifth century. It was part of a larger collection uncovered in the 18th century while the ancient Church was being rebuilt ${ }^{18}$.

He also goes into more detail:

The tablet portrays a scene with five servants. Four of them are positioning a man in front of a standing stone, laying his head on an indentation in the stone while the fifth one is trying to crush his head with a hammer. The scene is surrounded by the images of Holy Apostles Peter and Paul with halos or crowns over their heads. This stone tablet is near-identical to the original, which has been preserved and is still red from the blood of the eighty-tree soldier martyrs ${ }^{19}$.

It should be noted that some authors propose a different hypothesis: there are two witnesses who present a different and more concrete version of the same event. Despite the deeply rooted early Christian tradition with regard to the eighty-three soldier martyrs, some authors have formulated a rather risky hypothesis, namely that the soldiers were martyred by Arians or during the Lombard occupation of Amiternum and the surrounding village. The first hagiographer who included this information is B. Piazza. In Emerologio sacro he states that:

Eighty-three SOLDIER MARTYRS from Amiternum who were persecuted by Arians died a glorious death in the name of Jesus Christ. They were commemorated by St. Ignatius in the Roman Collage, where their famous Relics and two perfectly preserved ones where exhibited in the church sacristy ${ }^{20}$.

The remote possibility that the soldiers were martyred at the hands of Arians was criticized by G. Marangoni, who, in the end of the paragraph on the cemetery in San Vittorino and the Martyrs, states that:

Hinc hallucinatur Bartholomaeus Piazza, qui in suo Emerologio Sacro Romano sub die 24. Julii, scripsit Coronatos fuisse in persecuzione Arianorum: Subdit etiam, aliquot eorum Insignes Reliquias, necnon duo integra Corpora quiescere, \& coli in Ecclesia S. Ignatii Romae PP. Societatis Jesu ${ }^{21}$.

\footnotetext{
18 P. Domenico di Sant'Eusanio, L'Aquila Santa ..., ibid., p. 277.

19 Ibid.

20 C.B. Piazza, Emerologio sagro di Roma ..., ibid., p. 75.

21 G. Marangoni, Acta S. Victorini episcopi Amiterni..,. ibid., p. 33.
} 
It is apparent that the claim that the Martyrs were killed by Arians is truly a bold one. This false claim is of recent origin and, similarly to other mistakes about the Martyrs, is the result of the confusion of their cult with the cult of the bishop of Amiternum. In antiquity, they were venerated in a similar fashion and the cult of the Martyrs of Amiternum was almost absorbed by the "oppressive" presence of bishop Vicitorinus. This claims is also an example of the cult of the Martyrs being confused with the cult of Cetteo, a bishop and a martyr from Amiternum, who died at the hands of Arians.

The frequency with which the cult of the Martyrs of Amiternum is conflated with other, more important martyrs, such as Victorinus and Cetteo, emphasizes the will of the hagiographers to commemorate not only those saints whose cult is widespread and wellestablished but also those whose cult is weaker in comparison.

\section{In re obscura versantes. The complex hagiography of the martyrs of Amiternum and new ways of its interpretation Summary}

The lives of the eighty-three Martyrs of Amiternum have always left the few scholars who have studied them feeling frustrated and in need of closure. Scant reliable data and the lack of studies on the Amiternum Martyrs have compounded the mystery of a hagiographic issue that had already been difficult to understand. This paper doesn't claim to have solved this riddle, now consolidated and ingrained with the story of the martyrs. It is merely an analysis of the available hagiographic material that aims to offer new perspectives for further study based on the few reliable facts in the history of Martyrs of Amiternum.

Keywords: Martyrs of Amiternum, Amiternum, martyrium, Vittorin of Amiternum

About the author: Luca Capannolo Research interests: religious literature, hagiography, history of the Church 